\title{
Gotta face 'em all: Pokémon, Japanese animated characters, and the emergence of playful visual animism
}

\begin{abstract}
Vincenzo Idone Cassone ${ }^{1}$
Abstract. As a result of technological innovations and new cultural practices, the contemporary mediasphere is increasingly populated by digital(ized) faces. The phenomenon is not limited to human faces, but includes a vast universe of fictional animated faces, variously called 'characters', 'mascots' or 'kyara'. In Japan, while certainly not new, kyara have been spreading thanks to globalization, digitalization and media-mix strategies. Through the connection between visual design, fictional narratives and socio-cultural consumption, kyara can be considered semiotic figures of in-betweenness, key symbolic mediators in the Japanese mediascape. Their anthropomorphic face design mediates the cultural boundaries between the human and the non-human, the animate and the inanimate, nature and culture. Furthermore, their post-modern narratives mix inspiration from the past and the present, from myths to science fiction. Lastly, they involve an encyclopedic reworking between fiction and reality, mythical references and secularization, between the domains of seriousness and playful make-believe. The article aims to explore the semiotic dimensions of kyara in contemporary Japan, with emphasis on their logic of representation and cultural outcomes. These will be investigated through the analysis of the Pokémon franchise, which will make it possible to describe the emergence of new semiotic patterns of 'playful visual animism' in the process of media facialization of everyday life.
\end{abstract}

Keywords: Pokémon; playfulness; animism; heterotopy; faces; anthropomorphism; fan theory; transmedia

\section{Introduction}

The contemporary mediascape (Appadurai 1990) is increasingly populated by digital(ized) faces, combining an unprecedented quantity and quality of images, new forms of interaction and the emergence of face-based cultural practices and beliefs. This can be attributed to a mix of recent technological innovations (digital photography, visual filters, software for automatic face recognition), the diffusion of novel genres of face representation (the selfie, animojis, memes) and new behaviours/

1 Department of Humanities, University of Turin, Italy; e-mail: idonecassone@gmail.com. 
practices (swapping faces on apps for dating, using masks or occultation for political activism, covering faces for healthcare during pandemics) (Leone 2018).

While the vast majority of research studies have been focusing on human faces, the "facialization" of media cultures also includes the parallel pervasiveness of animated anthropomorphic faces. Animated characters and mascots are certainly not new, but have been proliferating in the last thirty years due to the combination of media globalization, digitalization and market strategies (Bendazzi 2016). As a result, the current global mediascape is filled with anthropomorphic characters such as Mickey Mouse, Hello Kitty or Pokémon (from transmedia franchises), Tony the Tiger, Michelin Man or the Linux penguin (representing corporate or brand identity), not to mention historic sport mascots or recent emoji-based characters (Tampa Bay's Raymond, Pusheen the cat, etc).

Their presence is even more significant in Japan, where they have been at the heart of media-mix strategies (Steinberg 2012) and media ecology dynamics (Ōtsuka 1989) since after WWII. The Japanese mediascape is filled with many of the above-mentioned anthropomorphic characters, often labelled ' $k y a r a$ ', not limited to child-targeted TV shows or toys. Kyara are part of daily brand merchandizing (Han 2017), and are used extensively for public and social advertising (Alt, Yoda 2007) as well as to embody local places and tourist attractions (Barrows 2014), and feature in parades and social events (Occhi 2012).

The importance of such characters in Japanese culture, however, does not simply lie in their pervasiveness. Their presence has been linked to a process of characterization in Japanese everyday life, in which kyara become "creatures of inbetweenness" (Nozawa 2013) ${ }^{3}$ : semiotic personae whose existence is not limited to specific media formats, visual styles or fictive semiospheres, but appears as fragmentary, pervasive and heterogeneous daily experiences of "characterencounters". Thus, they can be assimilated as key symbolic mediators (Lotman 1990: 136-137) in the Japanese semiosphere: figures which enable communication between the inner and outer layers of the cultural self-description systems (identity-alterity). In a similar way to their human correlates, the presence of and interaction with animated characters could be linked to the inception of new semiotic codes/models of behaviour (Lotman 1990: 233-234). More specifically, as

2 The Japanese term 'kyara' was born as an abbreviation of the loan word 'kyarakyutä, but now stands mostly for "highly-stylised or simplified visual figuration that can be easily reproduced and consumed outside of its original context" - see Galbraith 2009: 125; Galbraith, Patrick W. 2009. Moe: Exploring virtual potential in post-millennial Japan. Electronic Journal of Contemporary Japanese Studies 9(3) is available at https://www.japanesestudies.org.uk/ articles/2009/Galbraith.html.

3 Nozawa, Shunsuke 2013. Characterization. Semiotic Review 3 is available at: https://www. semioticreview.com/ojs/index.php/sr/article/view/16/67. 
I suggest in this paper, contemporary kyara could be related to semiotic patterns of playful animism in the Japanese semiosphere, which result from the interaction between the visual features of these characters, their roles and function in the mediascape, and the encyclopaedic interpretive behaviours of users.

The aim of this contribution is to describe the patterns of playful animism in the Japanese semiosphere, discussing them in relation to: the specific codes of visual representation of animated characters, the encyclopaedic logics of anthropomorphism, the interpretive process involved in interacting with fictional narratives, and the contemporary dynamics of media consumption. This objective will be pursued by using the global franchise of Pokémon as a case study.

Pokémon (haplology of 'pocket monster', 'poketto monsutā') is a well-known transmedia franchise, created in Japan by Satoshi Tajiri, Ken Sugimori and Junichi Masuda in the mid-1990s (1996) as a videogame for the Game Boy handheld console. The sudden success of the game in Japan led to the development of a media mix strategy, ${ }^{4}$ with the realization of an anime series (1997) which was quickly translated and exported into the USA (1998) and Europe (1999), fuelling the production of merchandise (collectibles, plushies, clothing, etc.) and subsequent development of movies, comics, other games, as well as theme parks, official parades, cross-branding and so on. Although many have predicted its decline over the years (Tobin et al. 2004), the franchise is still among the most widespread and highest-grossing in the world, with a further boost provided by the smartphone ARG Pokémon GO (2016) and the latest videogame entries Pokémon Sword/Shield (2019).

The Pokémon franchise proves to serve as a fitting case study for the understanding of the peculiar semiotic features of animated anthropomorphic characters for several reasons. First, it is a perfect embodiment of the contemporary changes in Japanese transmedia products and codes of narrative consumption, being an example of Steinberg's (2015) gameic media mix, ${ }^{5}$ as well as a narrative transmedia interactive ecosystem (Ōtsuka 1989). Second, it can be considered a paradigmatic example of Japanese culture while simultaneously being a globalized phenomenon, a syncretic mix of contemporary post-modern narratives and folkloric heritage (Iwabuchi 2002; Hutchinson 2019; Allison 2006). Lastly, as I suggest in this paper, the franchise could be read in light of Azuma's (2009) reflections on the otaku subculture as "the site that most sensitively registers social transformations" (Lamarre et al 2007: 158) in contemporary Japan.

$4 \quad$ 'Media mix' is a term initially used in Japan to indicate the commercial strategy of diversification of a brand through different products and media; the term has been diffused in the West by Steinberg (2012), who specifically discusses the anime-based media mix created around Astro Boy (Tetsuwan Atomu) in the 1960s.

5 A transmedia strategy centred on games and not anime, as for the anime media mix. 


\section{Visually iconic, taxonomically hybrid: The design of Pokémon}

Pokémon are among the most iconic contemporary animated characters in the world. In Japan, due to the success of the franchise and the extensive crossbranding and merchandise promoted by its media-mix strategy, Pokémon faces can constantly be seen on TV, in magazines, and in street advertisements; they are incorporated into clothes, food, vending machines, and even periodically feature in costume parades and events on the streets. The franchise mascot, Pikachu, as well as the most famous Pokémon of each generation, could be defined as proper contemporary cultural icons.

Despite the many differences in media formats (manga, anime, games), styles, illustrators, and the technological evolution (from 2D to 3D) of the games, the characters of the franchise are widely identifiable and visually distinct ${ }^{6}$. However, while it can be said that the visual features of Pokémon are generally recognizable and established in the Japanese cultural encyclopaedia, a different question arises in relation to their "taxonomy", or encyclopaedic categorization. More specifically, I suggest that while the semiotic competence linked to Pokémon recognition is relatively diffuse, it is somewhat difficult for model readers/users to explain and define what Pokémon actually are, according to typical cultural taxonomies.

In order to describe the zoomorphic features of the Pokémon themselves, Surace (2017) fittingly refers to them as 'animaloids'. While Pokémon are depicted as living and sentient creatures, their morphology largely oversteps the boundaries (both inner and outer) of the animal world. The design of the 898 existing Pokémon includes almost every known form from the animal kingdom (mammals, fishes, insects, gastropods, sponges, etc.) and inspiration from other kingdoms of life (plants, fungi, even protists). Pokémon design is also derived from non-living natural objects (minerals and rocks, metals, gases) and often goes beyond the boundaries of nature to include the artificial (mechanical Pokémon), as well as paranormal entities (ghosts, spirits, urban legends), extra-terrestrial forms (aliens, beings from parallel dimensions, digital Pokémon, robots) and even legendary or mythical beings (embodiments of nature, supernatural tricksters, fairies, transcendent beings) up to the Pokémon god itself. Furthermore, while

6 Part of the reason is connected to the media-mix nature of the franchise, which has circulated in many formats and media from the start. The appearance of many Pokémon, for instance, has become well known thanks to the widely used illustrations by Ken Sugimori (art director and character designer of Game Freak). For coherency purposes, the pictures on the following pages have been selected from Sugimori's illustrations, while the analysis has included the sprites, $3 \mathrm{D}$ models of the games etc. 
many Pokémon display anthropomorphic shapes, many others are clearly based on human artifacts (keys, garbage, ice creams) or figures/representatives of human activities (mimes, martial artists, gurus).

In addition to the variety in origin/inspiration, it should be pointed out that the vast majority of Pokémon display a heterogeneous mix of features/properties from different natural kingdoms: the animal, mineral, and vegetal worlds, as well as the overlapping of human, supernatural or daily elements, thus appearing as original chimeric/hybrid creatures (see Fig.1).

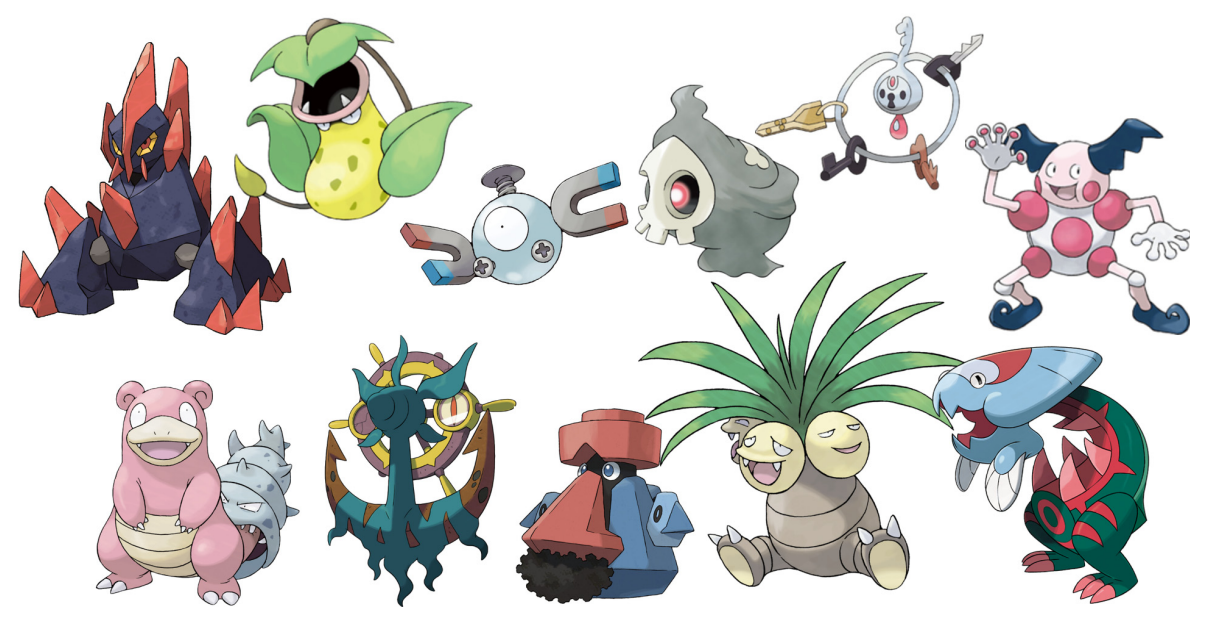

Figure 1. Left to right, up: Gigalith, Victribell, Magnemite, Duskull, Klefi, Mr. Mime; below: Slowbro, Dhelmise, Propobass, Exegutorr, Dracovish. (Copyright of Nintendo/The Pokémon Company/GameFreak, under Fair Use.)

It is indeed difficult to find a universally shared physical or biological feature common to all Pokémon, which would make them fit perfectly into a proper encyclopaedic categorization: from this perspective, Pokémon remind of Umberto Eco's reflections on the platypus as an object of experience which subverts the existing cultural segmentations and taxonomic codes of its viewers (Eco 2000) in a similar way to the cultural taxonomization of animals themselves (Maran, Martinelli, Turovski 2011), by involving semiotic issues which are linked to the coherency and structure of cultural self-descriptions (Madisson 2016), both real and fantastic, as showed by Borges' examples of the Chinese encyclopedia, and Marco Polo's description of unicorns (Eco 2000: 57-58).

What stands out in the case of Pokémon is, once again, their semiotic nature as animated beings, in a double meaning: as visual products of animation, and as 
characters which manifest animated traits. Etymologically, the deep connection between the appearance/effect of dynamism and the inherent assumption of agency and life which many cultures ascribe to the former can be expressed by the term 'animaloid'.

The hybrid and heterogeneous design of Pokémon also extends to the dynamics of anthropomorphism ${ }^{7}$ which is common, yet rarely investigated, in animation (Wells 2009: 2): on the one hand, the franchise establishes a clear and immediate visual and diegetic difference between humans and Pokémon (even if categorization provided in the diegetic universe turns out to be contradictory and complex); on the other hand, typical visual techniques of animation, employed in forms of character anthropomorphization, are applied to Pokémon, even if in heterogeneous ways. An example (albeit partial) can be provided by looking at the visual representation of faces and gazes in the franchise: their anthropomorphization is a common trope of animation, associated with the possibility of providing animals with human-like communicative and emotional expression abilities (Parkinson 2020: 43-50; Wells 2009: 29--32).

First of all, the vast majority of Pokémon (approximately 888 out of 898 ) can easily be interpreted as having a face, in terms of the presence of recognizable eyes/nose structure, associated with the communicative and emotional expression ability (Bruce, Young 2012: 253-260). Those lacking a visage are often diegetically regarded as exceptions (see Fig.2):

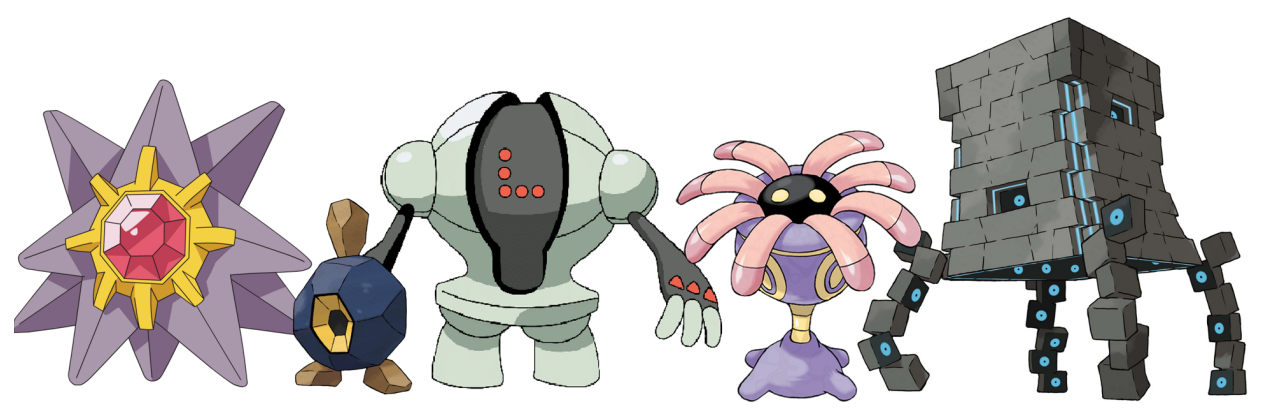

Figure 2. Pokémon with no face. Left to right: Starmie, Roggenrola, Registeel, Lileep, Stakataka.

7 In a semiotic perspective, anthropomorphism can be considered the adoption or interpretation of certain elements, features and affordances of characters as typically human traits (e.g. wearing clothes), or as human variants of more general traits of living beings (e.g. group behaviour, eating). In this perspective, anthropomorphism is always a perspectival dynamic, a result of broader cultural self-descriptions and encyclopaedic structures, which pre-establish the human-animal dichotomy in certain semiospheres (see Bertrand, Marrone 2019). 
In relation to the eyes and gazes of Pokémon, we can see a heterogeneous set of visual forms, ranging from a relatively anthropomorphic gaze (with visible white sclerae $^{8}$ ), to cartoon expressive gazes (conveying the attitudes or emotions of the characters), eyes inspired by the biological structures of mammals, insects, etc., or even certain forms of supernatural eyes (flames, gems, etc).

Despite this, the franchise tends to follow the traditional norms of cartoon animation (especially Japanese animation), by making eyes and gazes, as well as faces, fundamental communicative interfaces for meaning-making among living beings, including animated ones (Leone 2021); furthermore, as a typical trope of animation, both the anthropomorphic and the expressive gaze are often used for humans and Pokémon alike. This is evident in all the manga, anime and games since the second generation: the same visual expressive traits are used as the basis for certain Pokémon and human characters, or to express the same temporary attitude (see Fig. 3).
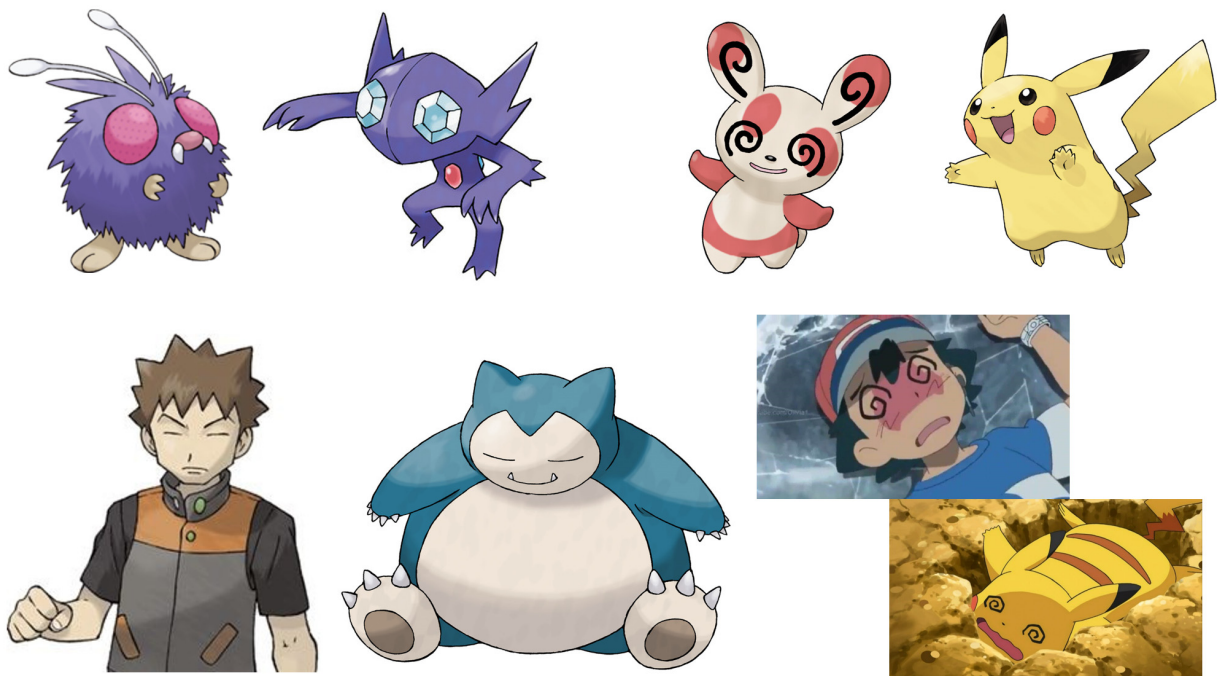

Figure 3. Up: different types of eyes in Pokémon; down: humans and Pokémon with similar gazes.

This example may support the initial assessment that the Pokémon universe seems to be characterized by the interaction of two simultaneous dynamics: on the one hand, the dynamic of visual animated-ness; on the other hand, a perceived

8 The presence of visible white sclerae in humans is considered an evolutionary trait (Kobayashi, Konshima 2001) typical of humans and certain apes, often interpreted and ascribed by cultures as a sign of humanity. 
taxonomic heterotopy. The former uses typical styles and techniques of animation (even if in heterogeneous ways) to ensure the recognition of Pokémon and humans alike as living, sentient creatures, sharing the communicative and expressive function of the face (Leone 2009, 2021); in case of the latter, the hybrid design of Pokémon does not simply deviate from, but actually challenges the interpreters' cultural codes of taxonomy, undermining their semiotic codes of segmentation between living and non-living, different kingdoms of nature, and the very perceived difference between the human and the animal, the cultural and the natural.

\section{Pokémon heterotopic regime of animation}

A likely critique of the idea introduced above is that the ways in which living beings are represented in Pokémon do not deviate from the standards of animation, more specifically those with fantasy settings and targeted at children/young adults. Animation typically involves anthropomorphizing of living and non-living beings, with magic- and fantasy-based narratives whose potential incoherencies are likely to trigger typical suspension of disbelief dynamics in spectators. According to Lamarre (2018), since the 1930s, the reflection on animation has often been linked to an implicit animistic attitude, it being the explicit representation of many natural phenomena as animated and provided with agency, as part of a general tendency to anthropomorphize animal and natural phenomena. However, as discussed by Wells (2009: 51-59), the representation and interpretation of animal characters as correlated with or reflecting humans is not completely homogeneous, with many examples of similar forms of deviation from traditional taxonomies in the representation of animals and humans in other globalized franchises.

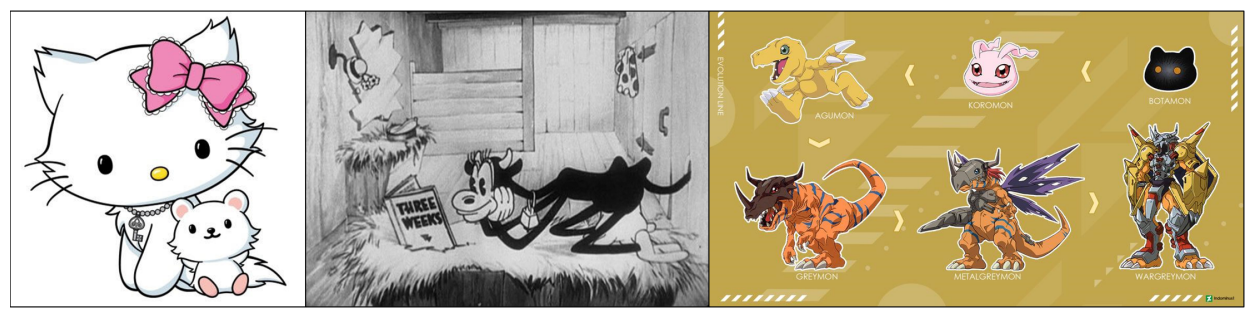

Figure 4. Examples from the franchises Hello Kitty, Mickey Mouse short movies, and Digimon. 
The various franchises (see Fig. 4) present similar abstract forms of representation of eyes and gazes, all sharing an implicit understanding of the face as the sign for the communicative and agentive capacity of "superior" living beings. What would thus be different or relevant about Pokémon? The answer can be found by comparatively analysing the ways in which the visual codes of representation interact with the diegetic codes and narrative dynamics of the different universes. This can be done according to two main dimensions of analysis:

- first, internal representational coherence, looking for ways in which the visual codes of representation confirm, deviate from or overlap the spectators' encyclopaedic taxonomies;

- second, visual/diegetic coherence, looking for ways in which the narratives reinforce, ignore or contradict the visual logic of representation and the spectators' taxonomies.

As concerns internal representational coherence, in many cases in traditional animation, despite the simultaneous presence of various degrees of anthropomorphic and zoomorphic characters, there are clear visual indicators (sign-index) which act as discriminators to ensure the taxonomic separation between the different classes. In Hello Kitty, for instance, only the human-like characters have clothes and the property of language, while Charmmy Kitty the pet has neither. Despite the clear sharing of animal visual traits, the cultural segmentation between humans and animals is conveyed through different visual sub-codes. This also happens in the modern (post-1950s) narratives of Mickey Mouse, in which the anthropomorphic characters share a common language and possess clothes (albeit in partially incoherent ways).

On the other hand, in the early Mickey Mouse short movies (up to the 1930s), as well as in other franchises such as Winnie the Pooh, Digimon and Yu-gi-oh, there is no coherent set of visual cues to ensure the stability of the spectators/ readers' encyclopaedic taxonomies described by Eco $(1975,1979)$. As regards clothing, there is the simultaneous presence of anthropomorphic animals with no clothes and others that are partially or fully clothed, although there is coherence in anthropomorphic behaviour and property of language. From this perspective, Pokémon is closer to the latter group, with the notable addition that the degree of its hybridism is far more pronounced than in traditional Western animation.

As concerns visual/diegetic coherence, Pokémon distances itself from the others in relation to the coherence between the visual and diegetic codes of representation. Most of the above-mentioned franchises interact with possible incoherence in internal representation either by ignoring it or by normalizing it through the diegetic dimension of the narratives, in an attempt to facilitate the interpreter's suspension of disbelief or to portray it in a comedic light. On the 
contrary, the anthropomorphism in Pokémon is both internally incoherent (with many Pokémon assuming various degrees of human traits, or being based on humans) and diegetically exposed. While certain Pokémon may raise fewer issues for the interpreter's cultural encyclopedia, others do so to various degrees, with the further fact that incoherencies are highlighted within the franchise itself, mainly through the descriptions in the PokéDex (the diegetic encyclopedia of the Pokémon Universe), as well as by meta-referential elements. The most notable examples are: - Behaviour: the ethologic descriptions in the PokéDex often focus on their physical attributes, instincts or basic behaviour, yet many Pokémon possess specific behaviours which duplicate or resemble cultural ones attributed to humans. Thus, Frostlass (\#478) freezes the travellers who reach its cave, then uses them as decoration for its home; Conkeldurr (\#534) invented, and taught humans how to make, concrete; Aggron (\#306) reclaims its territory after natural disasters, replanting trees and hauling topsoil. Some of these features are particularly incoherent because they are attributed to a species, while apparently describing unique characters (\#778 Mimikyu’s disguise, as well as Cubone’s skull).

- Clothing: while certain Pokémon are naked (or clothed by their masters), others include recognisable clothes in their design, from belts to ribbons to $g i$ and pants. Some of these items are explicitly stated not to be clothes, but parts of the Pokémon body (such as \#068 Machamp's champion's belt and briefs and \#560 Scrafty's loose trousers), while other Pokémon use clothes with no explanation (\#814 Raboot's hoodie, \#743 Ribombee's scarf); some Pokémon even sew them (\#542 Leavanny, when it encounters baby Pokémon); often, for many Pokémon no specifications are provided (\#539 Sawk's gi, \#107 Hitmonchan's boxing gloves).

- Food: in a world with no animals aside from the domestic/tamed Pokémon, the representation of food easily leads to diegetic inconsistencies. The games and anime openly mention and represent meat-like and fish-like dishes, with no elucidation. Simultaneously, sometimes the franchise clearly states that Pokémon are used as food (Chansey's eggs, Miltank's milk, Slowpoke's tails, as well as whole Farfetch'd, Cherubi, Sharpedo): the latest games in the series, Pokémon Sword/Shield, include the possibility of creating curry with what appear to be recognisable Pokémon parts (tails) or meat-like elements (hot dogs, meatballs).

- Death: while Pokémon cannot die directly in the games (they simply "faint", once defeated) and almost never die "onstage" in the anime/manga, death has been mentioned since the very first games, with a Pokémon graveyard and numerous examples of deaths from old age or by violence, many of which originate ghost 
Pokémon. A lot of the recent entries of the PokéDex discuss the violent and bitter deaths of humans/Pokémon which have made them become ghosts.

- Pokémon/human differences: besides humanoid Pokémon, there are problematic insights into the relationship between Pokémon and humans. In the fourth generation games, a fictional textbook in the Canalave Library reports that "once, humans and Pokémon married [...] they were the same" (Game Freak 2006). In the same games, the Pokémon God Arceus is stated to have created the universe, as well as Pokémon and humans. In the fifth generation games, the main antagonist $(\mathrm{N})$ grew up among the Pokémon and is able to talk with them. Furthermore, the PokéDex presents many cases of permanent transformations from human to Pokémon, for instance Kadabra (\#64), Phantump (\#708) and especially Yamask (\#562): once human, now Pokémon, the latter carries its own past face as a mask, in order to find people who may remember it.

- Comedic/serious attitude: while the Pokémon franchise mostly follows the comedic attitude and its traditional targets are children and young adults, there are many sudden variations in tone, for instance in the city of Lavender in the first game, as well as certain other dark/bitter/unsettling PokéDex entries: Pokémon killing people by mistake (\#760 Bewear), dying in pain because of their masters (Mega evolutions), abducting children (\#425 Driftloom), presenting fatal biological conditions (\#325 Spoink) or being damned/ extinguished due to climate change (\#864 Cursola).

In conclusion, the Pokémon universe manifests a higher degree of visual and diegetic incoherency in comparison to other contemporary or traditional animated franchises: its explicit taxonomic heterotopy, and the dynamic of visual animatedness, are supported and strengthened by internal diegetic and visual incoherencies leading to what I would call a general heterotopic regime of animation. The apparent self-contradictions and incoherencies are not ignored or normalized; instead, they are highlighted and reinforced through the metareferential aspects and contrasting tones of the internal self-description system of the PokéDex. Many of the above-mentioned examples also involve clear cases of ludo-narrative dissonance (Seraphine 2019) ${ }^{9}$, making gameplay and narratives openly clash during the games.

9 Seraphine, Frederic 2019. The rhetoric of Undertale - Ludonarrative dissonance and symbolism. Digital Games Research Association JAPAN, Proceedings of 8th Conference. 2019. Available at: https://www.researchgate.net/profile/Frederic-Seraphine/publication/323545890_ The_Rhetoric_of_Undertale-Ludonarrative_Dissonance_and_Symbolism/links/ 5a9bdb8545851586a2acea7d/The-Rhetoric-of-Undertale-Ludonarrative-Dissonance-andSymbolism.pdf. 


\section{Visual animism and playful interaction}

A notable example is represented by Pokémon \#778 Mimikyu, who embodies both the self-contradictory taxonomy of the franchise and a clear case of its metareferential and self-communicative (Lotman 1990:20) nature. Mimikyu is a ghost/ fairy Pokémon which, as it says in the PokéDex, uses a rag in order to disguise itself as Pikachu and hide its true, terrifying appearance. According to other descriptions, this Pokémon suffered from extreme solitude, and thus decided to take over Pikachu's mantle in order to make new friends as the yellow mouse was so famous. Mimikyu is a notable case of meta-reference in Pokémon, in which the diegetic universe hints at the artificial nature of the franchise by referring to an "external" world where Pikachu is not just a Pokémon among others, but the franchise mascot, or more precisely, its face.

Many long-term fans have appreciated the meta-referential elements of the franchise such as Mimikyu, ${ }^{10}$ (or the eighth generation fossil Pokémon) ${ }^{11}$, elaborating many fan theories that try to address the most glaring contradictions in the franchise (below).

The success of Pokémon may suggest that its heterotopic nature and declared diegetic self-contradictions have been accepted and have now culturally developed into a proper set of semiotic dynamics, with their own visual codes of representation and diegetic structures, which have a clearly recognizable role in the mediasphere. Pokémon, in itself, could thus be paradigmatically used to discuss the manifestation of much subtler changes in certain semiotic codes of behaviour related to animated faces.

Following Lotman and Lévi-Strauss, it should be remembered that fictional narratives and myths, both traditional and modern ones, interact with cultural self-models and contribute to their strengthening or weakening. Thus, as stressed by Tønnessen and Tüür (2014), as well as Bertrand and Marrone (2019), any form of textualized categorization of otherness (whether non-human animals, nonliving beings, or non-natural entities) in relation to the subjectivity (we humans), interacts with and takes part in the many codes shaping the human semiosphere. Animals, spirits, gods and inanimate beings are classified and interpreted according to cultural taxonomies and placed in specific parts of the cultural self-description systems of the semiospheres, depending on their relationships with the core forms

10 Websites of internet culture such as Kotaku and Polygon have dedicated several articles to fan reaction surrounding Mimikyu; such as https://www.polygon.com/2016/7/19/12225262/ pokemon-sun-and-moon-new-pokemon-mimikyu.

11 See https://www.polygon.com/2019/11/22/20977707/pokemon-sword-shield-fossildracozolt-arctozolt-dracovish-arctovish-pokedex-england-fake. 
of subjectivity of the system itself. As a result, the ways in which even fictional narratives display and describe animals (or animaloids) through texts, pictures and daily practices can highlight significant dynamics of the semiosphere, especially in connection with the principal aspect of the face (and its representation) as a key semiotic interface for communication among living beings, which is now being increasingly textualized in the media system.

In my view, the many above-mentioned visual and narrative features of the Pokémon franchise may show two significant cultural dynamics which have been emerging in the contemporary Japanese semiosphere in recent times: the first is a logic of visual animism of characters; the second is a regime of playful interaction with the animated.

In relation to the former, we can refer to Descola's (2013) four-fold schemas of nature/culture ontologies to understand Pokémon franchise logic as an animist ontology: simply put, divergences in exteriority may exist between the different conceived natural and cultural kingdoms, but there is a shared community in their interiority. Furthermore, as previously discussed, the world of Pokémon often leans towards what Descola would call a totemic ontology, which is characterized by a community of both interiority and exteriority. This is the result of the frequent simultaneous hybridizations, heterotopies and undermining of the encyclopaedic boundaries between species, natural kingdoms, and what is natural, artificial or cultural.

Within this heterotopian ontological system, the representation of faces acts as a double-layer mediatory interface. First, as previously discussed, the face is the paradigmatic interface for human communication, linking the somatic and the semiotic, the natural and the cultural. Anthropomorphic and expressive animated faces make communication possible between humans and Pokémon, both among characters and in relation to the reader, even though they do not share a language, because of their shared gestural and expressive codes as sentient beings.

Moreover, on the level of media representation, anthropomorphic face representation acts as a mediatory interface between the heterotopian (animist/totemist) ontology of Pokémon and the common naturalist ontology of the public/viewers. By following the tropes of traditional animation, facial representation makes it possible to control and reduce the encyclopaedic uncanny (das unheimliche, see Foucault 1967), translating it into something understandable, inoffensive, even cute and worthy of affection (inheriting the kawaii aesthetics, see Kinsella 1995).

An indirect example of this dynamic of facial representation is provided by the uncanny effects generated by its removal/modification in the recent film Detective Pikachu (2017). The CGI + live action movie is set in the Pokémon universe, yet in order to ensure coherence between CGI and real actors, the directors chose to 
abandon the typical visual flatness of the anime and video game. Instead, they adopted a "realistic" representation of Pokémon, ${ }^{12}$ showing and animating in detail their fur and skin, eyes and gaze, bones and muscles. Despite the movie's success, this choice sparked a debate on the internet over the unsettling results: ${ }^{13}$ the representations of several Pokémon were interpreted as problematic or slightly disturbing (Jigglypuff, Psyduck, Lickitung) exactly because of the substitution of typical anime stylization/flatness with iconic bodily and zoomorphic traits. Among the many, the most notable was a highly uncanny and creepy representation of the (above-mentioned) humanoid Pokémon Mr. Mime (Fig. 5). The texturing of its skin (lights, skin pores), together with the motion-capture animation and perfectly acted gaze, in relation to its already anthropomorphic form/behaviour, gave rise to both disturbance and amusement, eliciting comparisons of this Pokémon to the unsettling clown in the film It and to Chucky the doll.
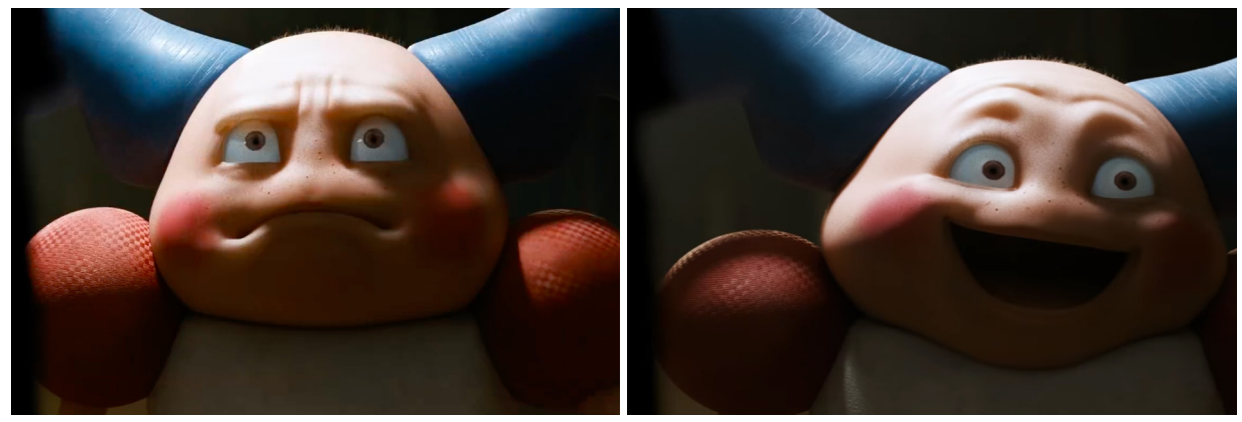

Figure 5. Mr. Mime in Detective Pikachu.

This example brings us to the second dynamic, the regime of playful interaction with the animated. As anticipated in the previous pages, it is very common for fans of the franchise to highlight the many inconsistencies and ludo-narrative dissonances of Pokémon. However, rather than leading to negative evaluations and disengagement, this often results in positive playful mocking and the development of fan theories to address the clear inconsistencies. Mr. Mime is again a fitting example, because of the long-lasting theories involving Ash's (the main character in the anime) lack of a father, who is never shown or discussed in the anime.

12 See https://www.wired.co.uk/article/pokemon-detective-pikachu-cgi.

13 See https://www.huffpost.com/entry/realistic-pokemon-from-detective-pikachu-arecreeping-people-out_n_5beb41e1e4b0caeec2bef1ff. 
According to this theory, Ash's true father is his mother's Mr. Mime (Mimey) which/who has lived under the very same roof since the boy was young, does a lot of housework, uses clothes and accompanies his mother on vacation, and never stays in the Pokéball. The theory goes further by hinting at many disparate plot elements and trying (in a comedic way) to explain all of them by means of the relationship between Ash and Mimey.

The many hundreds of Pokémon theories on the net ${ }^{14}$ rarely try to prove themselves true; instead, they continuously shift between being half-serious and half-facetious, simultaneously maintaining certain stances and their reversal, according to the specific notion of playful communication defined by Bateson (1956), according to a playful regime of interaction, as the paradoxical process of make-believe, in which the logic paradox itself is staged (i.e. 'to play fight' for children is simultaneously to fight as if doing so seriously, and to know one is not really fighting at all).

Internet fan cultures (both Japanese and Western ones) react to the incoherence, meta-referentiality and heterotopic taxonomy in Pokémon in a playful way. Fans take advantage of parts of ludo-narrative or diegetic incoherence in order to search playfully for possible alternative explanations or re-interpretations, doing so with an ironic distance, a tongue-in-cheek attitude. They search seriously for coherence with their encyclopaedic everyday codes, which involves a complex and time-consuming (re)interpretive process of the franchise's countless texts; yet, the results are often parodic and equally self-contradicting, if not more convoluted, clearly because of the fun afforded by the ridiculous consequences of this search for coherence, which ignores many typical narrative tropes of animation.

This very logic of interaction is encouraged and adopted by the authors and managers of the franchise, who purposely do not focus on strong internal narrative coherence, willingly presenting meta-references, contradictions among texts and within them, playful communication with fans and audience. For instance, the explicitly incoherent nature of the PokéDex descriptions has led to the fan theory that its entries were written by the ten-year-old characters of previous games, ${ }^{15}$ thus explaining the Pokémon individualization, the impossible measurements, the conflicting entries and descriptions by rumours, and so on.

14 See https://www.thegamer.com/classic-pokemon-fan-theories-believe-true/.

15 See https://www.cbr.com/pokemon-fan-theory-pokedex-creepy-entries/. 


\section{Playful visual animism in Japan}

My hypothesis is that the connection between an animistic visual logic of representation and a logic of playful interaction is increasingly common in the Japanese mediasphere, despite often being assimilated to traditional tropes of animation. In the following pages I discuss how what I label 'playful visual animism' can be identified in other daily practices linked to the presence of animated faces in Japan, and in their connection to pre-existing cultural dynamics and semiotic codes.

Many authors have highlighted the massive presence of animated characters (or kyara, see Occhi 2010, Wilde 2019, Sutera 2016) in Japanese society. 'Kyara' is a generic term which includes anthropomorphic franchise mascots, characters from manga and anime, as well as human figures used for brands or communication (imeeji kyara). Kyara proliferate in Japanese society as part of the above-mentioned media mix strategies, being extensively used for both large and small brands, being adopted for gadgets and merchandizing, diffusing the kawaii aesthetics, and even taking part in parades in costume (kigurumi) and receiving official recognition from the Japanese government.

In addition to the ubiquitous brand kyara, Alt and Yoda (2007) highlight the existence of the so-called working characters/service characters (hataraku kyara; Wilde 2018), which proliferate in daily metropolitan life, being utilized in road signs, municipal announcements, political advertizing and everyday object packages (see Fig. 6). Both anthropomorphic and zoomorphic (Miller 2010), these characters act as mediators of everyday life, giving indications and directing the behaviour of passers-by, reminding us of social norms, wishing good luck and fulfilling other apotropaic functions. They act in a similar way to Latour's petit Robert (see Latour 1992): whereas the mechanical boy replicated by figurization the agentivity of the user of the machinery, these characters embody and replicate the affective communicative dynamics of the participants in the semiotic encounter (be it a purchase, warning, advice, etc). Nozawa (2013) argues that everyday characters are the bearers of a semiotic ideology that cannot be reduced to functional anthropocentrism: because of their multiplication and frequency of interaction in daily life, as well as their relationships with other phenomena of human-character embodiment (vocaloids, kyara actors and personae) they manifest a semiotic ontology of transition that unites people and characters, animals and animates, the ordinary and the fictional, coherence and inconsistencies. 

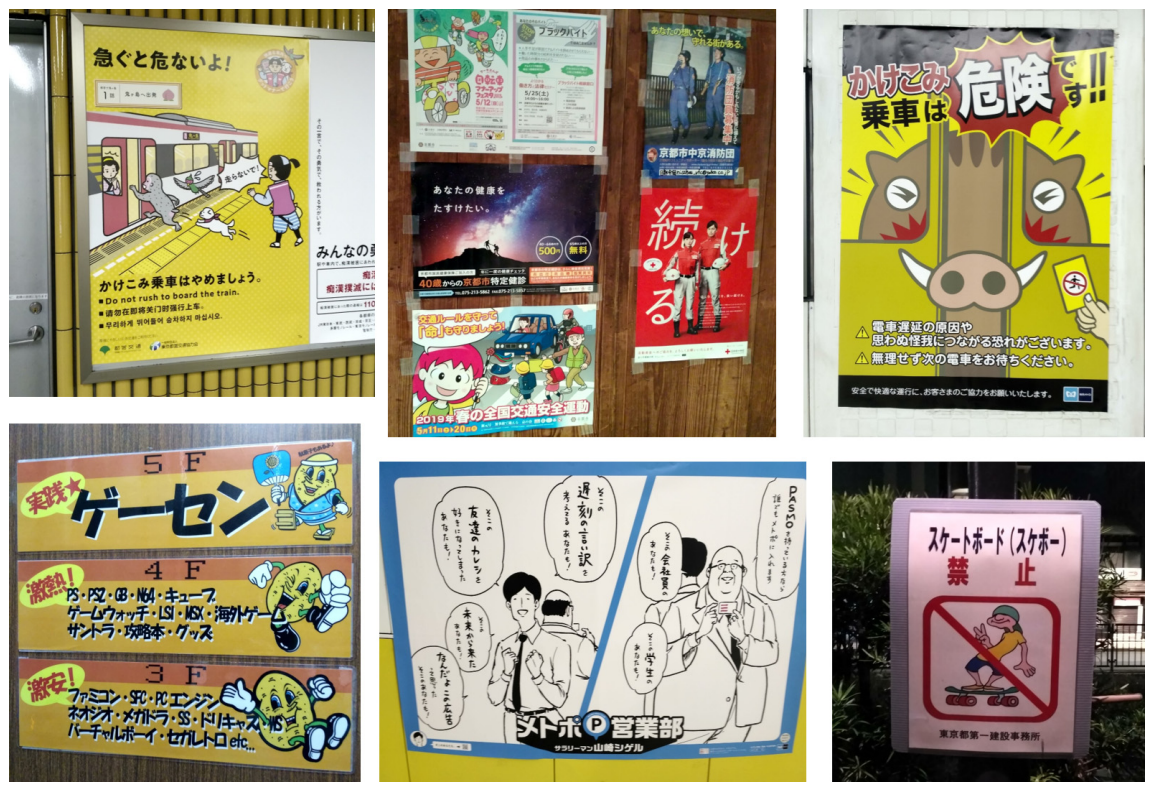

Figure 6. Service characters in Japan (the author's photos).

In addition to hataraku kyara, yuru kyara (or Gotōchi-kyara; Occhi 2014) are increasingly common in Japan. Taking their name from the wobbly, imprecise drawings which constitute them, these characters are often linked to local places, events or products. Despite their simplistic aesthetics, they frequently present hybrid forms, mixing the natural and the cultural, the zoomorphic and the anthropomorphic, combining in their simple representation typical products, myths and folklore, lifestyles and stereotypes. Incorporating kawaii aesthetics and neotenic characteristics (Kinsella 1995), they may feature a double nature: twodimensional on one side, mascot in costume (kigurumi) on the other, at times participating in specific local parades and national competitions (see Fig. 7).

Occhi (2012) has linked these characters to the religious animist traditions of Japan, by regarding them as secularized/popularized forms of the genius loci: anthropomorphic folkloric imagery (kappa, tanuki, kitsune) or the representation of vital forces and spirits (kami) that manifest themselves in the natural world. With the notable difference that, whereas the genius loci mediated between the supernatural and the sensible, the yuru kyara and hataraku kyara become mediators of an earthlier civic, promotional or commercial message, while often acting as emotional support, linked to a sense of relief, comfort and regression (Kondo 2006), partially confirmed by the attested use of kyara in modernized omamori. 


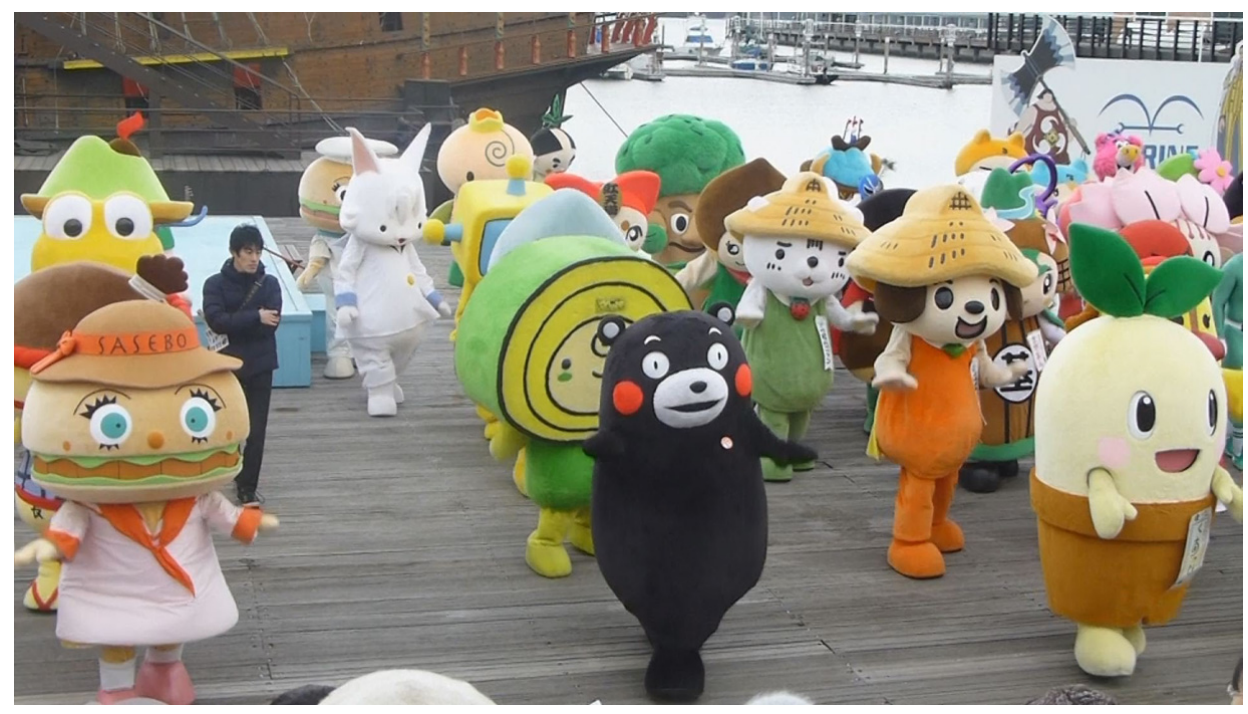

Figure 7. Yuru kyara in kigurumi form.

The religious and mythic dimensions of these kyara further highlight the ludic regime of interaction with them, shifting between seriousness and playfulness. Moreover, this is linked to the long-term tradition which connects acting, playfulness and devotion through religious practices. This confirms Foster's (2009: 13) assertion about the persistence of yōkai (Japanese supernatural spirits and entities) in the cultural imagination because of their ability to pivot between the credible and incredible. This link is clear in the traditional matsuri performances, as well as in the "play of the gods" (kami asobi; Plutchow 1996), and is, to a degree, reproduced in a secularized form, in the kigurumi parades and television mascot competitions. The ludic nature of these secularized religious practices, mediated by characters, makes possible the paradoxical communication (see Bateson 1956) which simultaneously includes affective approach and cognitive distancing.

Once observed through the double perspective of visual animism and playful interaction, these phenomena (and Pokémon) show further connections with certain semiotic characteristics of contemporary postmodernism. Azuma (2009; see also Lamarre et al. 2007) describes the Japanese shift in the 1990s from the logic of the postmodern as a narrative to that of the postmodern as a database, suggesting that Otaku culture could be considered the most sensible place to observe this change. In what he labels the animalization era, the logic of narrative coherency is substituted by the affective logic of the database, which, in Lotmanian terms, acts as a selfmodelling system (Madisson 2016). Texts based on the self-model of the database 
involve micro-narratives, centred on specific characters, themes and aesthetics which can be subject to infinite remodelling, with no essential traits connected to the characters. What remains is not the coherent personality traits, but rather the affective relationship between the user and the character.

As a result, an interesting parallel develops between the logic of the database and the dynamics of the collection, which is the way in which people interact with intangible characters: explicitly, in the case of Pokémon, and cognitively for kyara in general. On the one hand, the collection is a model of organization of the sensory in a playful form; on the other hand, the collection is a reorganization of the world into a microcosm of affections. Foster (2009: 214), for instance, points out the ludic and taxonomic similarities between Pokémon and yōkai, which could also be expanded to the contemporary interaction and communication with the above-mentioned kyara. These long-term dynamics are reproduced in the contemporary world, placed in a media circuit of production, sharing, interaction and evaluation. As I suggested in the introduction, this further strengthens the idea of Pokémon as an emblematic case study for the understanding of the semiotic dimension of animated characters in the Japanese mediasphere.

\section{Conclusion}

The examples discussed above indicated how the Japanese mediascape is permeated with anthropomorphic characters and faces, ranging from narrative transmedia franchises to branding, to merchandise, as well as an increasing presence in internet and fan culture. I have suggested how their spread may be connected to the emergence of specific semiotic behavioural codes and as a result of the interaction between the codes of visual representation of these anthropomorphic characters, their fictional narratives and the sociocultural patterns of interaction between humans and characters. Characters become key symbolic mediators (Lotman 1990) of everyday life, as well as "semiotic figures of in-betweenness" (Nozawa 2013: 8) in the semiosphere.

Through the analysis of the Pokémon case study, I defined two interrelated features: a logic of visual animism of characters; and a regime of playful interaction with the animated. These dynamics need not be limited to the Pokémon franchise, but can be attested in many anthropomorphic face-based characters and practices in the Japanese media system and culture. The resulting patterns of playful visual animism may help understand the intersection between visual stylized representation, the database-logic of media, fan culture behaviour and cultural appropriation of technologies in Japan. 
These dynamics may be correlated with recent changes in the semiotic dynamics of the Japanese media system over the last few decades, namely its process of globalization (Daliot Bul, Otmazgin 2020; Pellitteri 2018), its participation in the convergence culture and contemporary transmedia dynamics (Jenkins 2006; Scolari 2009; Saldre, Torop 2012), and its relationships with the broader dynamics of internet culture.

\section{References}

Appadurai, Arjun 1990. Disjuncture and difference in the global cultural economy. Theory, Culture \& Society 7(2/3): 295-310. https://doi.org/10.1177/026327690007002017

Azuma, Hiroki 2009. Otaku: Japan's Database Animals. Minneapolis: University of Minnesota Press.

Allison, Anne (ed.) 2006. Millennial Monsters: Japanese Toys and the Global Imagination. Vol. 13. Berkley: University of California Press. https://doi.org/10.1111/j.1467-9655.2007. 00472_9.x

Alt, Matt; Yoda, Hiroko 2007. Hello, Please! Very Helpful Super Kawaii Characters from Japan. San Francisco: Chronicle Books.

Barrows, Lissa 2014. Planning with Character: Gotouchi Kyara and Place Branding in Japan. [Unpublished Master's Thesis, M.Sc.] New York: Columbia University.

Bateson, Gregory 1956. The message "This is play". Group Processes 2: 145-241.

Bendazzi, Giannalberto 2016. Animation: A World History. Vol. 3: Contemporary Times. Boca Raton: CRC Press. https://doi.org/10.4324/9781315720746

Bertrand, Denis; Marrone, Gianfranco (eds.) 2019. La sfera umanimale. Roma: Meltemi.

Bruce, Vicky; Young, Andrew W. 2012. Face Perception. London, New York: Routledge. https://doi.org/10.4324/9780203721254

Daliot-Bul, Michal; Otmazgin, Nissin 2020. The Anime Boom in the United States: Lessons for Global Creative Industries. Leiden: Brill.

Descola, Philippe 2013. Beyond Nature and Culture. Chicago: University of Chicago Press. https://doi.org/10.7208/chicago/9780226145006.001.0001

Eco, Umberto 1975. Trattato di semiotica generale. Milano: Bompiani.

Eco, Umberto 1979. The Role of the Reader: Explorations in the Semiotics of Texts. Bloomington: Indiana University Press.

Eco, Umberto 2000. Kant and the Platypus: Essays on Language and Cognition. Boston: Houghton Mifflin Harcourt.

Foster, Michael Dylan 2009. Pandemonium and Parade: Japanese Monsters and the Culture of Yokai. Berkeley: University of California Press. https://doi.org/10.1525/9780520942677

Foucault, Michel 1967. Let mots et les choses: Une archéologie du savoir. Paris: Gallimard.

Game Freak 2006. Pokèmon Diamond/Pearl. Nintendo.

Han, Ruobin 2017. The Characterization of Japan. From marketing to Identity. [Unpublished Ph.D. Thesis in Humanities.] Leiden: University of Leiden.

Hutchinson, Rachel 2019. Japanese Culture Through Videogames. London, New York: Routledge. https://doi.org/10.4324/9780429025006 
Iwabuchi, Koichi 2002. Recentering Globalization: Popular Culture and Japanese Transnationalism. Durham: Duke University Press. https://doi.org/10.1515/9780822384083

Jenkins, Henry 2006. Convergence Culture: Where Old and New Media Collide. New York: New York University Press.

Kinsella, Sharon 1995. Cuties in Japan: Women, media and consumption in Japan. In: Moeran Brian; Skow, Lise (eds.), Women, Media and Consumption in Japan. London: Routledge, 220-254.

Kobayashi, Hiromi; Kohshima, Shiro 2001. Unique morphology of the human eye and its adaptive meaning: Comparative studies on external morphology of the primate eye. Journal of Human Evolution 40(5): 419-435. https://doi.org/10.1006/jhev.2001.0468

Kondo, Kensuke 2006. Hyaku nen ai sareru kyarakutaa no tsukurikata. [How to create characters that will be loved for one hundred years.] Tokyo: Goma Books.

Lamarre, Thomas 2018. Animation and animism. In: Boehrer, Bruce; Hand, Molly; Massumi, Brian (eds.), Animals, Animality, and Literature. Cambridge: Cambridge University Press, 284-300. https://doi.org/10.1017/9781108595278.017

Lamarre, Thomas; Azuma, Hiroki; Furuhata, Yuriko; Steinberg, Marc 2007. The animalization of Otaku culture. Mechademia Second Arc 2(1): 175-187. https://doi.org/10.1353/ mec. 0.0023

Latour, Bruno 1992 Where are the missing masses. In: Bijker, Wiebe E.; Law, John (eds.), Shaping Technology-Building Society: Studies in Sociotechnical Change. Cambridge: MIT Press, 225-259.

Leone, Massimo 2009. Agency, communication, and revelation. Lexia 3/4: 77-95.

Leone, Massimo 2018. The semiotics of the face in the digital era. Perspectives 17: 27-29.

Leone, Massimo 2021. On muzzles and faces: The semiotic limits of visage and personhood. International Journal for the Semiotics of Law/Revue internationale de Sémiotique juridique 34(2): 1-24. https://doi.org/10.1007/s11196-020-09812-8

Lotman, Yuri. M. 1990. Universe of the Mind: A Semiotic Theory of Culture. London: IB Tauris.

Madisson, Mari-Liis 2016. Self-description. In: Rodriguez Higuera, Claudio Julio; Bennett, Tyler James (eds.), Concepts for Semiotics. (Tartu Semiotics Library 16.) Tartu: Tartu University Press, 204-212.

Maran, Timo; Martinelli, Dario; Turovski, Aleksei (eds.) 2011. Readings in Zoosemiotics. Vol. 8. Berlin: Walter de Gruyter. https://doi.org/10.1515/9783110253436

Miller, Laura 2010. Japan's zoomorphic urge. ASIANetwork Exchange: A Journal for Asian Studies in the Liberal Arts 17(2): 69-82. https://doi.org/10.16995/ane.208

Occhi, Debra J. 2010. Consuming Kyara 'characters': Anthropomorphization and marketing in contemporary Japan. Comparative Culture 15: 77-86.

Occhi, Debra J. 2012. Wobbly aesthetics, performance, and message: Comparing Japanese Kyara with their anthropomorphic forebears. Asian Ethnology 71(1): 109.

Ōtsuka, Eiji 1989. Monogatari shōhiron. [A Theory of Narrative Consumption.] Tokyo: Shinyosha.

Pellitteri, Marco 2018. Kawaii aesthetics from Japan to Europe: Theory of the Japanese "cute" and transcultural adoption of its styles in Italian and French comics production and commodified culture goods. Arts 7(24): 1-24. https://doi.org/10.3390/arts7030024 
Plutschow, Herbert 1996. Matsuri: The Festivals of Japan: With a Selection from P.G. O'Neill's Photographic Archive of Matsuri. London, New York: Routledge.

Saldre, Maarja; Torop, Peeter 2012. Transmedia space. Crossmedia Innovations: Texts, Markets, Institutions 51: 25-44.

Scolari, Carlos Alberto 2009. Transmedia storytelling: Implicit consumers, narrative worlds, and branding in contemporary media production. International Journal of Communication 3: 586--606.

Sutera, Jillian Rae 2016. Who is Hikonyan? The phenomenon of Japanese Yuru-Chara. Sociology 6(12): 775-782. https://doi.org/10.17265/2159-5526/2016.12.004

Surace, Bruno 2017. Zoosemiotica dei Pokémon. In: Marrone, Gianfranco (ed.), Zoosemiotics 2.0: Forms and Policies of Animality. Palermo: Edizioni Museo Pasqualino, 609-619.

Steinberg, Marc 2012. Anime's Media Mix: Franchising Toys and Characters in Japan. Minneapolis: University of Minnesota Press. https://doi.org/10.5749/minnesota/ 9780816675494.001.0001

Steinberg, Marc 2015. 8-Bit Manga: Kadokawa's Madara, or the gameic media mix. Kinephanos: Journal of Media Studies and Popular Culture 5: 40-52.

Tobin, Joseph (ed.) 2004. Pikachu's Global Adventure: The Rise and Fall of Pokémon. Durham: Duke University Press. https://doi.org/10.2307/j.ctv1131ctc

Tønnessen, Morten; Tüür, Kadri 2014. The semiotics of animal representations: Introduction. In: Tønnessen Morten; Tüür, Kadri (eds.), The Semiotics of Animal Representations. Leiden: Brill Rodopi, 7-30. https://doi.org/10.1163/9789401210720_002

Wells, Paul 2009. The Animated Bestiary: Animals, Cartoons and Culture. New Brunswick: Rutgers University Press. https://doi.org/10.36019/9780813546438

Wilde, Lukas R. A. 2018. Character street signs (hyōshiki): "Mangaesque" aesthetics as intermedial reference and virtual mediation. Orientaliska Studier 156: 130-150.

Wilde, Lukas R. A. 2019. Kyara revisited: The pre-narrative character-state of Japanese character theory. Frontiers of Narrative Studies 5(2): 220-247. https://doi.org/10.1515/ fns-2019-0014

\section{Gotta face 'em all: покемоны, японские анимационные персонажи и появление игрового визуального анимизма}

В результате развития технологий и новых культурных практик современная медиасфера всё больше заселяется цифровыми лицами. Это явление не ограничивается человеческими лицами, но включает в себя множество вымышленных анимированных лиц, называемых «персонажами», «маскотами» или kyara. Явление kyara, давно известное в Японии, широко распространяется благодаря глобализации, цифровизации и технологиям медиа-микширования. Таких персонажей, соединяющих области визуального дизайна, вымышленных историй и социокультурного потребления, можно считать семиотическими знаками промежуточности, ключевыми символическими медиаторами в японском медиапространстве. Антропоморфный дизайн их лиц стирает культурные границы между человеком и не-человеком, одушевленным и неодушевленным, природой и культурой. Кроме того, постмодернистские истории, 
частью которых они являются, вдохновлены прошлым и настоящим, мифами и научной фантастикой. Наконец, они подразумевают энциклопедическую переработку на границе между фантастикой и реальностью, мифическим и секулярным, игрой и реальностью. В статье рассматриваются семиотические измерения kyara в современной Японии с акцентом на логику их репрезентации и культурное влияние. Анализ франшизы «Покемо́н» позволяет описать возникновение новых семиотических паттернов «игрового визуального анимизма» в процессе медийного «олицетворения» повседневной жизни.

\section{Gotta face 'em all: Pokémonid, Jaapani animategelased ning mängulise visuaalanimismi esiletõus}

Tehnoloogiliste uuenduste ning uute kultuuripraktikate tulemusena sisustavad kaasaegset meediasfääri ühe enam digi(taliseeritud) näod. See nähtus ei piirdu inimnägudega, vaid siia kuulub ka fiktsionaalsete animanägude suur universum; neid nimetatakse 'tegelasteks', 'maskottideks' või 'kyara'. Kuigi kyara pole Jaapanis uus ilming, on nad hakanud levima tänu globaliseerumisele, digitaliseerumisele ja kombineeritud meedia strateegiatele. Visuaalse disaini, fiktsionaalsete narratiivide ja ühiskondlik-kultuurilise tarbimise seoste kaudu võib kyara't pidada semiootilisteks vahepealsuskujudeks, Jaapani meediamaastiku peamisteks sümboolseteks vahendajateks. Nende antropomorfne näodisain vahendab kultuurilisi piire inimliku ja mitteinimliku, elusa ja elutu, looduse ja kultuuri vahel. Lisaks seguneb nende postmodernsetes narratiivides minevikust ja olevikust lähtuv inspiratsioon müütidest ulmeni. Ning viimaks tähendavad nad entsüklopeedilist ümbertöötlemist, mis leiab aset väljamõeldise ja tegelikkuse, müütiliste osutuste ja sekulariseerumise, tõsiduse ning mängulise teeskluse valdkondade vahel. Artikli eesmärgiks on uurida kyara semiootilisi mõõtmeid tänapäeva Jaapanis, rõhuasetusega nende representatsiooniloogikale ja kultuurilistele tagajärgedele. Neid käsitletakse, analüüsides Pokémoni frantsiisi, mis võimaldab kirjeldada "mängulise visuaalanimismi" uute semiootiliste mustrite esiletõusu igapäevaelule media poolt nägude omistamise käigus. 